Article

\title{
Segmenting the Generation Z Cohort University Students Based on Sustainable Food Consumption Behavior: A Preliminary Study
}

\author{
Irene C. Kamenidou *, Spyridon A. Mamalis, Stavros Pavlidis and Evangelia-Zoi G. Bara \\ Eastern Macedonia Thrace Institute of Technology (EMaTTech), 65404 Agios Loukas Kavala, Greece; \\ mamalis@econ.auth.gr (S.A.M.); stavrospavlides@yahoo.gr (S.P.); evaeva13@hotmail.com (E.-Z.G.B.) \\ * Correspondence: rkam@teiemt.gr; Tel.: +30-251-046-2157
}

Received: 13 November 2018; Accepted: 30 January 2019; Published: 6 February 2019

\begin{abstract}
In-depth knowledge of sustainable food consumption behavior regarding university students, and especially the younger ones, reveals tendencies of the worlds' sustainable future. This study aims to explore the sustainable food consumption behavior of the Generation $\mathrm{Z}$ cohort (18-23 years of age) that is studying at Greek universities and living away from home, and to segment them according to their behavior. Quantitative research was implemented with an online questionnaire, which resulted in a collection of 252 valid samples. The results revealed that the focus of sustainable food consumption behavior is limited to eating seasonal fruits and vegetables and purchasing regional food. Additionally, it identified two student segments based on sustainable food consumption behavior.
\end{abstract}

Keywords: sustainable food consumption; consumer behavior; sustainability; university students; Generation Z cohort; marketing; Greece

\section{Introduction}

Consumer choices concerning food have a significant impact on the environment [1], since they are drivers of agricultural production. Prior research indicates that agriculture affects the environment and its resources to a great extent [2,3], due to many influencing factors, amongst which are the industrialization of agriculture, food processing and consumption patterns [4]. Consequently, choices regarding food consumption signify importance from an environmental prism [5], and thus, a sustainable food consumption pattern is desired in order to preserve natural resources for future generations. Sustainable food consumption (SFC) has been linked to different consumption dimensions, such as consuming local products, decrease in meat consumption and processed products [6], increase in fruit and vegetable consumption [7], and generally consuming products that have small ecological, carbon and water footprints.

While a great number of published research papers focus on SFC $[4,8-12]$, there is no unanimously-accepted definition $[4,13]$, although one of the most commonly-used definitions is provided by FAO [14]. SFC is an umbrella term which encompasses environmentally-sound food choices (e.g., organic foods), animal welfare and fair trade [15].

SFC has been studied from different angles. Research includes fair trade [16,17], animal welfare [8,18-20], the environmental impact of food production, marketing, as well as consumption [21-23]. With respect to consumer behavior, a wide body of studies refer to SFC by reducing meat consumption [19,24,25], and consuming locally-produced products [26-29]. Also, some studies explore the consumption of organic foods $[26,30,31]$ and waste behavior $[8,32,33]$. Others focus on attitudes, perceptions, and other aspects of sustainable food consumption behavior [12,34-37], pointing out 
the influence of social norms on SFC behavior [12,38-40], or profiling the green consumer [41-43]. Furthermore, certain studies focus on barriers that hinder the adoption of SFC behavior [44-46], while a great amount of research focuses on different countries and consumers' SFC behavior $[31,39,47]$. The aforementioned published studies constitute only a sample of aspects associated with SFC.

Although a plethora of studies focus on sustainable food choices and consumption behavior, studies on consumer segmentation and sustainable food choices are still limited [15]. Against this background, the present paper aspires to explore the question of whether university students studying in Greece belonging to the Generation Z (Gen Z) cohort (18-23 years of age) have adopted SFC behavior. It also intends to proceed to segmentation based on this behavior. Specifically, it addresses the following research questions, which it attempts to answer:

1. What are the eating patterns of university students belonging to the Gen $Z$ cohort?

2. Do university students of the Gen $\mathrm{Z}$ cohort exhibit SFC behavior?

3. Do people important to these students consider that university students belonging to the Gen $Z$ cohort should adopt SFC behavior?

4. Are university students who belong to the Gen Z-cohort willing to change the point of purchase of their food if the provider is ecologically irresponsible?

5. How can the Gen Z cohort university students be grouped, based on their SFC behavior and attitudes?

6. What is the profile of each segment?

Since discrete segments of SFC behavior were found within other research frames [39,48,49], it is important to explore segments of students in the Gen $\mathrm{Z}$ cohort, taking into account that the corresponding literature review is limited on the issue. Consequently, the main hypothesis of this research is that discrete groups of students with different SFC behavior are expected to exist.

The targeted sample group consists of university students that live away from their families and who are members of the Gen $Z$ cohort. Preceding studies have recognized the significance of using generational cohorts in consumer behavior [50] and marketing [51], and as a result, generational cohort marketing is considered very valuable due to the uniform behavior of cohorts [52]. Generational cohorts are individuals born within a specific time range and at a specific place, who undergo the same life-changing events while 17-23 years of age [53]. The specific generation cohort has been selected since it is a group of individuals that now live on their own and must make the necessary food and consumption decisions [54]. The relevant literature provides mixed results regarding the food consumption behavior of university students. Some previous studies have demonstrated that students who live away from home make poor dietary choices [55-57] in comparison to those living at home [57]. On the other hand, they are being educated, and as prior research has indicated, education effects SFC [58,59]. Specifically, educated people are more inclined to make sustainable food choices and adopt a sustainable diet [60-62]. Thus, this issue needs to be further investigated. Moreover, Vantamay [63] emphasizes that university students have the freedom to choose their consumption behavior, as opposed to school students, who are mainly affected by their parents' choices; therefore, they are regarded as a suitable consumer group for the promotion of sustainable consumption behavior. Furthermore, it is of huge importance to comprehend sustainable food choices, diets and consumption behaviors of university students of the Gen $\mathrm{Z}$ cohort, as these will be the future parents as well as the educational, political, social and financial elites that will shape the sustainable consumption and development policies of future societies.

While numerous studies have already focused on SFC, the added value of this study is that it fills the following gaps in the literature:

1. It focuses on Gen $Z$ cohort consumers, i.e., people born between 1995-2009 [51]. The consumers of this generational cohort are an emerging topic in the marketing field [54,64]. As Priporas et al. [64] (p. 375) rightly point out, "this generation seems to be the biggest future marketing challenge"; 
2. it focuses on university students' sustainable food behavior, which is an understudied subject [65], imposing the need for more studies (search in Google Scholar yielded 110 results for "sustainable consumption behavior/our" and "university students", while "sustainable food consumption" and "university students" yielded 311 results);

3. while several studies have been found focusing on SFC and university students, studies on a combination of SFC, university students, and the Gen $\mathrm{Z}$ cohort are extremely scarce. To our knowledge, only three studies refer to this matter [66-68]. This provides grounds for more research on this issue, since this group is considered as important to study, constituting, as mentioned, the future elite.

This paper is organized as follows. In the next section, a literature review is provided, followed by the research methodology applied. Afterward, the study results are presented and elaborated, as well as the conclusion of the study. The paper concludes with the limitations and directions for further research.

\section{Literature Review}

As already stated, there has been extensive research on SFC, even though it is a relatively novel subject of research (following the 1994 Oslo Roundtable on Sustainable Production and Consumption). Lorenz and Langen [8] provide an extensive and in-depth literature review of 110 papers related to food choice and consumption out of the home, and they offer grounds for SFC behavior. Rana and Paul [69], having reviewed the literature on consumer behavior and purchase intention for organic food, concluded that in developed countries, factors such as the environment, health, and knowledge significantly influence consumers' buying behavior and purchase intentions, whereas in developing countries, the need for safety is the main force for demand for organic products.

As regards university students, the literature suggests that there are many barriers preventing consumers from buying environmentally-friendly products. Činčera et al. [70], in their study with respondents from different consumer groups in the Czech Republic, found that lack of trust in the concept of sustainable consumption and consumers' personal history play an important role in consumer decision-making. More precisely, only mothers and students from the respondents' pool have explicitly expressed favorable attitudes towards sustainable consumer behavior. An earlier study in universities in Europe, North America, and Australia identified the perceived cost of sustainable food, together with a lack of knowledge, time and availability, as ubiquitous barriers preventing university students from adopting more sustainable eating habits [71].

A very recent study in Italy [72] revealed that food convenience and certifications are the key factors influencing university students' food choices. Deliens et al. [73] revealed that Belgian university students' eating behavior is influenced by individual factors, their social networks, physical environment, and the macro environment. Additionally, their eating behavior is moderated by university characteristics, such as residency, student societies, university lifestyle, and exams. Another study conducted by De Groeve and Bleys [74] in Belgium explored if business students were willing to support six Less Meat Initiatives (LMIs) that were going to be implemented in the student restaurant. They found that student support was rather limited, and that higher environmental concern is associated with higher support for all LMIs.

Ahamad and Ariffin [75], in their study in Malaysia, demonstrated a high level of sustainable consumption knowledge, contrary to a moderate level of sustainable consumption attitudes and practices among university students. In the same vein, an earlier study in Belgium among youngsters revealed that low perceived availability of sustainable products explains why intention to buy remains low, although attitudes might be positive [12]. Similarly, a new study in Italy divulges that the visibility and understanding of sustainability-labeled foods are currently very low among young adults [76]. Furthermore, Vantamay [60], applying the theory of planned behavior (TPB) as a theoretical framework, investigated Thai undergraduate students' sustainable consumption behavior. His findings indicated 
that attitudes toward the behavior, subjective norm, and perceived behavioral control could co-predict sustainable consumption behavior.

Furthermore, with regard to segmentation, very few studies deal with university students in the context of SFC. A study run in Italy with university students $(n=500)$ identified three different consumer types, namely, the responsible food consumer, the potentially sustainable food consumer, and the inattentive food consumer. These segments were derived based on attitudes toward sustainable foods such as organics, animal-friendly, fair-trade, local, and respectful of workers' rights. The responsible food consumer and the potentially sustainable food consumer segment presented higher interest levels and awareness of sustainability issues in food than the second cluster (the inattentive food consumer). However, these two segments differ, because the potentially sustainable food consumer segment has smaller Mean Factor Scores in almost all cases, compared to the responsible food consumer. The responsible food consumer consists mainly of older participants (29-34 years old), urban citizens, whose families have medium-high household incomes, and are green consumers. On the other hand, the potentially sustainable food consumer cluster considers it difficult to find and purchase sustainable food products, and even though they are sensitive to food sustainability issues, they are inactive in applying sustainable behavior. They are participants from rural areas and with their families having an average household income. Finally, as regards the inattentive food consumer cluster, they are the younger students (18-24 years old) from non-urban areas and with families that have an average household income [77]. Aprile and Mariani [78], in their study in Italy with undergraduate students regarding their attitude towards sustainable labels of food products, identified four segments: students orientated to sustainability labels, kind-hearted students, power seekers, and environmentalists.

Lastly, previous studies on the topic that have focused on or include the Gen Z cohort and SFC, to our knowledge, are very few [66-68]. Fiala et al. [66], with an eye-tracking experiment, in-depth interviews, and the A/B testing method, explored the Gen Z approach to local food in general (apple juice, cream, gherkins, flour, a children's snack (Hamánek), mead, paprika and yogurt) and the impact of its labelling (an eco-label, a local-label or a bio-label) on their perceptions. The sample consisted of 121 participants (63 in the reference group A, and 58 in the control group B). Participants were requested to rank their attitude toward products with Regional Food labeling. The results revealed that the participants had no greater interest in the brand of the products just because of the presence of the label. Bogueva and Schmidinger [67], using online qualitative research methods, examined the meat-eating patterns and social readiness and acceptability of new meat alternatives amongst Australian Gen Y $(n=119)$ and Gen Z $(n=108)$ consumers. Their research on social readiness and acceptability of new meat alternatives focused on four issues: as normal, natural, necessary, and nutritious. They found that the vast majority of the respondents (79.3\%) eat meat very frequently (several times per week up to every day). While a small percentage eats meat occasionally (12.8\%), and an even smaller group doesn't eat meat at all (7.9\%). They also found that concerning the question of whether the idea of consuming meat alternatives is normal, answers were equally divided as normal and abnormal (by both generational cohorts), and from those that considered it normal, about one-third of them considered meat alternatives as natural to consume. Regarding the question of whether it is necessary to consume meat alternatives (for sustainability), this was confirmed by $87.2 \%$ of the participants. Finally, regarding the question of whether meat alternatives are perceived as nutritious, 82.2\% "shared immense uncertainty about the meat alternatives' nutritional values." It is pointed out that, even though this research concerns the Gen Z and Gen Y cohorts, results by cohort or comparisons are not made, except as regards the "normality" of alternative meat consumption. Lastly, Beretzky and Jámbor [68] explored Gen Z university students nutrition habits and found that most of the students reported that they held a rather healthy lifestyle. They reported that they consume fruits or vegetables at least once daily and eat fast food once or twice a week, and they do not prefer purchasing groceries from local markets, but from supermarkets. 


\section{Materials and Methods}

This research applied a multistage method. In the first stage, a thorough literature review provided an insight of the components and dimensions of SFC and dietary patterns (e.g., [11,12,77-82]). The literature review provided the questions and scales that were considered and used in the final questionnaire. For the research presented in this paper, and regarding the question referring to self-reported eating patterns, the question was adopted from Aarnio and Lindeman [81], and one more eating pattern was added ("I am a junk food eater") from qualitative research. Concerning the SFC behavior, the statements were: Avoid food products with excessive packaging (AV1), buy regional food products (PUR1), avoid food products imported by airplane (AV2), eat only seasonal fruits and vegetables (EAT1), buy organic food (PUR2), and eat less meat, maximum once or twice per week- EAT 2 (adopted from Tobler et al. [79]), eat sustainably farmed fish (EAT 3), eat meat types with lower environmental impact (EAT 4), eat organic meat (EAT 5), eat hybrid meat types (MPS1), eat plant-based meat substitutes (MPS2), and willing to take protein from insects- MPS3 (adopted from Vanhonacker et al. [11]). Furthermore, three questions regarding SFC were added that were derived from qualitative research: Avoid consumption of any imported agricultural products and foodstuffs (AV3), avoid buying or consuming ready-made prepacked foods (AV4), and purchase fruit and vegetables in bulk form (PUR4). Lastly, two questions, one referring to social norms and the other regarding purchasing behavior, were also included in the study. From Vermeir and Verbeke [49] was adopted and modified the statement referring to social norms: "People who are important to me believe that I should have a lifestyle that is related to a sustainable consumption of agricultural products and food". From Roberts [82] was adopted the ecological purchasing behavior item: "I will not buy agricultural products and food if the company that sells them is ecologically irresponsible" (ethical behavior).

The second phase employed qualitative research with twelve university students in order to confirm the questions used. Specifically, one focus group with six participants (one per each age 18-23) and six depth interviews (one student per age of 18-23) were implemented with university students belonging in the Gen $\mathrm{Z}$ cohort, selected on a convenience basis. In this phase, the conversation dealt with their eating patterns, food consumption behavior, perceptions of sustainable eating patterns, and how possible it is to change their eating patterns and behavior to make them more sustainable in the future. Students' perceptions, opinions, and behavior were recorded and were cross-checked with the items in the questionnaire. The discussions were recorded digitally (with the interviewee's permission) to increase the accuracy of data collection $[64,83]$, and transcribed. This resulted in adding the three questions mentioned above that dealt with SFC behavior. In order to determine validity, a Facebook account was opened especially for this study, to which the 12 students participants were invited with a code to access a copy of the analyzed data to confirm their authenticity, avoid any misinterpretations of the researchers' understandings, and in this way, establish member validity [84].

The third phase pretested the data collection instrument to ensure that the questionnaire was functional, to verify if changes were needed, and to ensure face validity [85], implemented in two manners. The first was through the internet (one day/15 participants) where, at the end of the questionnaire, comments about the wording, functionality, scales or any other comment that would improve it, were requested. The second was after class, with students answering the questionnaire and providing feedback (103 students). The pilot test showed wording changes and modifications of the scale that was adopted from Tobler et al. [79] had to be implemented. Specifically, for the SFC behavior, the scale used after it was modified was 1 (negative behavior) to 7 (positive behavior): $1=\mathrm{I}$ am not doing this, and I am not willing to do it ever, 2 = I am not doing this, and I am not willing to do so in the far future (long-run), $3=\mathrm{I}$ am not doing this, and I am not willing to do this in the near future, $4=\mathrm{I}$ am not doing this and will think about it in the future if I will do it (neutral), $5=\mathrm{I}$ am doing this occasionally (whenever I can), $6=\mathrm{I}$ am doing this already very often, 7 = I am already doing this, and I consider that I will continue doing it forever. The scale was considered as a summated scale in order for reliability analysis to be executed [86]. The questions regarding social norms and ethical 
behavior were rated on a 7-point Likert scale, where $1=$ Completely disagree to $7=$ Completely agree, with $4=$ the neutral point, i.e., neither disagree nor agree.

In the fourth stage, the questionnaire was finalized, and the field research took place. The questionnaire was created in google docx form and was distributed via the internet for data collection, employing a non-probability mixed sampling method (criteria, convenience, and snowball sampling). Criteria were used for a person to be considered as a sample unit. In order to participate in the research, individuals had to be university students in Greece, with age 18-23, and live away from home. Students were invited personally and through Facebook to take part in the research if they fell in the above criteria. They were requested to go to the Facebook account that was opened and were provided with the link, the research objectives, the criteria for participating, and consent for using the data gathered (first question in the questionnaire). It also pointed out that the confidentiality of answers was provided and there was no link to the students [87]. Lastly, it requested students to forward the link to friends that met these criteria too, regardless of the region and the university in which they studied. The link was accepting responses from March to September 2018. By this procedure, at first, 262 questionnaires were gathered, but only 252 were considered appropriate for the analysis, i.e., they fulfilled the criteria of the research.

The survey was approved by the members of the Department of Business Administration of the Technological Educational Institute of Eastern Macedonia and Thrace (EMaTTech) with reference number 3/EH $\Delta-31.1 .2018$ and conducted with the direct consent of each respondent.

The analysis included descriptive statistics, reliability, factor, cluster analysis, and crosstabulations. As regards content validity of the questions referring to the student's SFC behavior, the content validity of previous researchers $[11,49,79,82]$ was relied upon, while the total reliability of the scale (15 items) was $\alpha=0.809$, which was considered acceptable [88]. Additionally, convergent validity, with average variance extracted (AVE), and composite reliability (CR) was measured of each multi-item construct (Table 1), using the equation of Fornell and Lacker [89]). The AVE result for construct No.1 was $0.492<0.5$, and for construct No. 2 it was $0.436<0.5$. Even though the result of AVE is $<0.5$, AVE $>0.4$ is accepted, since CR in both cases are $>0.7$, and thus, the convergent validity of the construct is still acceptable [89]. Furthermore, discriminant validity was assessed by using the Fornell and Lacker [89] criteria. Fornell and Lacker [89] considered that discriminant validity is established when the correlations among the constructs are lower than the square root of the average variance extracted. (The first diagonals represent the square root of the AVE while the other entries represent the correlations.) The results show discriminant validity was established. Lastly, the significance level in all hypothesis testing procedures was preset at $\alpha=0.05(p \leq 0.05)$.

Table 1. Test for convergent and discriminant validity.

\begin{tabular}{lcccc}
\hline SFC Behavior Constructs & Construct 1 & Construct 2 & Construct 3 & Construct 4 \\
\hline Construct $1(n=4)$ & 0.701 & & & \\
Construct 2 $(n=5)$ & 0.467 & 0.660 & & \\
Construct $3(n=3)$ & 0.324 & 0.386 & 0.816 & \\
Construct $4(n=3)$ & 0.203 & 0.331 & 0.049 & 0.757 \\
AVE & 0.492 & 0.436 & 0.666 & 0.574 \\
CR & 0.793 & 0.788 & 0.855 & 0.800 \\
Cronbach $\alpha$ of construct & 0.720 & 0.719 & 0.768 & 0.667 \\
\hline
\end{tabular}

Source: The authors. AVE: average variance extracted; CR: composite reliability.

\section{Results and Discussion}

\subsection{Sample Profile}

Table 2 presents the samples' profile. The majority of the sample were females, with three age groups being most prominently represented (19, 20 and 22 years old). Furthermore, the larger percentage has as permanent residence cities, and are from Northern Greece (Region of Eastern 
Macedonia and Thrace and Region of Central Macedonia). Lastly, as regards their net family monthly income, the majority falls into the $1000.01-2000.00 €$ range. It is pointed out that family income was measured since university students are financially supported by their parents.

Table 2. Profile of Generation Z University student cohort.

\begin{tabular}{lcc}
\hline \multicolumn{1}{c}{ Sample Characteristics } & Frequencies & Percentages (\%) \\
\hline Gender & & \\
Male & 114 & 45.2 \\
Female & 138 & 54.8 \\
Age & & \\
18 & 35 & 13.9 \\
19 & 60 & 23.8 \\
20 & 54 & 21.4 \\
21 & 35 & 13.9 \\
22 & 57 & 22.6 \\
23 & 11 & 4.4 \\
Marital status & & \\
Single & 231 & 91.7 \\
Married & 18 & 7.1 \\
Divorced/widowed & 3 & 1.2 \\
Area of residence & & \\
City & 195 & 77.4 \\
Town & 33 & 13.1 \\
Village & 24 & 9.5 \\
Net Monthly Family Income (in euros) & & \\
$\leq 1000.00$ & 72 & 28.6 \\
1000.01-2000.00 & 130 & 51.6 \\
2000.01-3000.00 & 43 & 17.0 \\
Z3000.01 & 7 & 2.8 \\
Region of residence & & \\
Region of Eastern Macedonia and Thrace & 99 & 39.3 \\
Region of Central Macedonia & 47 & 18.7 \\
Region of Attica & 31 & 12.3 \\
Other regions of the country & 75 & 29.7 \\
\hline
\end{tabular}

Source: The authors.

\subsection{University Students Generation Z Cohort Eating Patterns}

Regarding the self-reported eating patterns of university students belonging in the Gen $\mathrm{Z}$ cohort (research question no. 1), results reveal that the vast majority of the sample is omnivorous (83\%), few avoid eating meat or do not eat meat at all ( $8 \%)$, while no participant is vegan. Additionally, nine percent of university students characterized themselves as junk food eaters.

Furthermore, students were asked about their cooking patterns. The self-reported cooking patterns reveal that Gen Z students mostly either cook and rarely eat out or have food delivery $(45.6 \%)$, or eat at the student's restaurant and cook too $(23.4 \%)$. Furthermore, $11.9 \%$ reported that they eat at the student restaurant and eat out or have food delivery, and $9.1 \%$ stated that they rarely cook and mainly eat out or have food delivered. Only a very small percentage $(6.8 \%)$ reported that they cook at home and never eat out or have food delivery, and were thus considered students with healthy eating habits. Lastly, 3.2\% reported that they never cook and eat out exclusively, or have food delivery, eating fast food such as gyros and pitta souvlaki that it is ready to eat, easy, satiating and cheap. These students are (as self-reported) entirely "junk food eaters".

As previous research points out, eating behavior is influenced by individual factors, lifestyle, social networks, physical environment, university life and macro environment [73]. For example, many students tend to select food according to convenience, taste, time, and price [55]. Sogari et al. [90], in their research regarding college students, found that barriers to healthy eating were (amongst others) 
time constraints, stress, the high price of healthy food, and easy access to junk food. They also found that parental food behavior and friends' social pressure influence eating habits.

\subsection{Sustainable Food Consumption Behavior}

Table 3 presents the university students' SFC in Mean Score (MS) and Median per item (research question no. 2). The scale used is presented in the methodology section ( $1=$ negative behavior up to 7 = positive behavior). Table 3 reveals that the mean scores of the items are very close to the median scores, ensuring that the mean score is a reliable central tendency index. Results reveal that students' SFC behavior is limited to occasionally: eating only seasonal fruits and vegetables $(\mathrm{MS}=5.46)$, purchasing regional products $(\mathrm{MS}=5.10)$, and purchasing fruit and vegetables in bulk form $(\mathrm{MS}=4.99)$.

Table 3. Sustainable food consumption behavior.

\begin{tabular}{|c|c|c|}
\hline Statements & MS & Median \\
\hline 1. Eat only seasonal fruits and vegetables (EAT1) & 5.46 & 6.00 \\
\hline 2. Buy regional food products (PUR1) & 5.10 & 5.00 \\
\hline 3. Purchase fruit and vegetables in bulk form (PUR4) & 4.99 & 5.00 \\
\hline 4. Eat less meat, maximum once or twice per week (EAT2) & 4.34 & 4.00 \\
\hline 5. Avoid buying or consuming ready-made prepacked foods (AV4) & 4.30 & 4.00 \\
\hline 6. Buy organic food (PUR2) & 4.26 & 4.00 \\
\hline 7. Avoid food products with excessive packaging (AV1) & 4.19 & 4.00 \\
\hline 8. Avoid consumption of any imported agricultural products and foodstuffs (AV3) & 4.18 & 4.00 \\
\hline 9. Eat meat types with lower environmental impact (EAT4) & 4.05 & 4.00 \\
\hline 10. Eat sustainably farmed fish (EAT3) & 4.01 & 4.00 \\
\hline 11. Eat organic meat (EAT5) & 3.94 & 4.00 \\
\hline 12. Avoid food products imported by airplane (AV2) & 3.88 & 4.00 \\
\hline 13. Eat plant-based meat substitutes (MPS2) & 3.60 & 4.00 \\
\hline 14. Eat hybrid meat types (MPS1) & 3.25 & 3.00 \\
\hline 15. Willing to take protein from insects (MPS3) & 2.54 & 2.00 \\
\hline
\end{tabular}

Source: The authors; MS: Mean Score; $N=252$.

Results reveal that participants are not reducing their meat consumption to once or twice per week $(\mathrm{MS}=4.34)$ at the moment, but will think about it in the future. Our findings are partially consistent (as regards the intention to eat less meat) with those of De Groeve and Bleys [74], who found that the students' support of the 'less meat initiatives' in student restaurants was limited. In the same vein are participants' answers as regards "Avoid buying or consuming ready-made prepacked foods" (MS = 4.30). Participants' answers imply that they have moved away from the Mediterranean diet to a more westernized one. This is in line with previous research, which shows that people in the Mediterranean region have moved away from the Mediterranean diet and adopted a westernized diet [91,92]. The Mediterranean diet is high in fruit and vegetable intake and low in meat (four times per month), with primary sources of fat being fish and olive oil [93], and avoidance of consuming processed food [94]. In this regard, the Mediterranean diet is considered by many as a SFC diet $[5,95]$.

Additionally, as regards purchasing of organic food (MS $=4.26$ ) and eating organic meat (MS $=3.94)$, the results reveal that participants are not doing so now but will think about it in the future. This could probably be a consequence of the economic crisis on their family income. Prior research has shown a link between high income and purchasing organic products. Specifically, high income positively affects organic purchase behavior and vice versa [96,97]. Greeks have experienced extreme cutoffs in their income, they are heavily taxed, and poverty has risen. Thus, today the buying power of their income has been dramatically reduced [98], which prohibits people from purchasing organic food since they are considered more expensive compared to conventional foods [99]. Future behavior of these participants may change if they are in better financial conditions.

Moreover, concerning purchasing food with excessive packaging (MS =4.19), again, participants are not doing so at present but will think about it in the future. One probable explanation is that participants consider that excessive packaging is more durable, of better quality, and thus, that it 
better protects the product. Another explanation could be that excessive packaging is more appealing, one reason being that it may use "visual Storytelling" [100]. One more reason is that it may produce multisensory perceptions which affect purchase behaviors [101]. Hultén [101] (p. 9) states "In a global consumption culture with generations $\mathrm{X}, \mathrm{Y}$ and $\mathrm{Z}$ as target groups, it is evident that individuals use more than one sense in their multi-sensory brand-experiences."

With reference to avoiding the consumption of any imported agricultural products and foodstuffs (MS = 4.18) and avoiding food products that were imported by airplane (MS = 3.88), both MS reveal that if the product suits their needs, the Gen $\mathrm{Z}$ cohort does not care if products are imported. One explanation could be that they refer to agricultural products or foods that are not produced in Greece (such as bananas), and in order to avoid alteration of the product, a fast transfer must occur, i.e., by plane. As for their answers to the statements "Eat only seasonal fruits and vegetables" (MS = 5.46), "Buy regional food products" (MS = 5.10), and "Purchase fruit and vegetables in bulk form" (MS = 4.99), in all cases, the participants' answer is "I am doing this occasionally (whenever I can)". These behaviors are the closest as they come to SFC. These are actions that they can do with much ease, especially when purchasing fruits and vegetables. This implies that due to economic constraints, they purchase their raw food products from the weekly "Laikes" (big street markets of the area). The Laikes supply mainly local, seasonal, and in bulk form agricultural products, which are cheaper than the supermarket.

Lastly, whatever has to do with the new trends in SFC, i.e., eating hybrid meat types, plant-based meat substitutes, and taking protein from insects are not considered by the students to do so even in the far future. A reason for this is that insect-eating is not in the Greek food cultural context. Also, regarding insects, our findings are in line with those of Vanhonacker et al. [11], who found that participants had negative attitudes towards the consumption of insects, contrasting studies where university students were ready to accept novel foods such as insects [102,103] in their diet. Moreover, previous studies showed that European consumers are reluctant to eat insects because it is considered disgusting [104].

\subsection{Attitudes Towards Sustainable Food Consumption Behavior}

Table 4 presents the answers (mean score and median) of the two added statements, one referring to social norms (SN) and SFC, and the other referring to ethical behavior, i.e., EB (research questions no. 3 and no. 4). Previous research emphasizes that social norms (or subjective norm) is a predictor of food consumption behavior and consists of external social pressure to adopt (or not) a specific behavior [49], and "is concerned with people's motivation to comply with the beliefs of important referents" [105] (p. 6). In the same vein, Higgs and Thomas [106] point out that the "appropriate eating norms" are established by other people. Since the Global Citizenship Research regarding the Gen Z cohort [107] (p. 10) states that traditional sources, i.e., parents (89\%), friends $(78 \%)$ and teachers $(70 \%)$, influenced their values, it is important to explore whether social norms influence Gen Z SFC behavior.

Table 4. Attitudes of the Generation $\mathrm{Z}$ university students.

\begin{tabular}{lrl}
\hline \multicolumn{1}{c}{ Statements } & MS & Median \\
\hline $\begin{array}{l}\text { People who are important to me believe that I should have a lifestyle that is related to a sustainable } \\
\text { consumption of agricultural products and food (SN) }\end{array}$ & 4.35 \\
$\begin{array}{l}\text { I will not buy agricultural products and food if the company that sells them is ecologically irresponsible (EB). } \\
\text { Source: The authors; } N=252 .\end{array}$ & 4.28 \\
\hline
\end{tabular}

The second variable, ethical behavior (EB), deals with the consumer "who perceives a more direct link between what is consumed and the social issue itself" and "upon ethical consequences of his or her behavior" [12] (p. 2). Thus, one dimension is avoiding "unethical" companies [108]. According to Cooper-Martin and Holbrook [109], the majority of the studies that have examined ethical consumer behavior focus on environmentally concerned consumers and how these concerns affected their consumer behavior. Therefore, it is important to explore whether ethical consumption behavior is part of the Gen Z cohorts' SFC behavior. 
Results reveal that respondents in both cases have a neutral attitude, i.e., they tend to neither agree nor disagree $(1=$ Completely disagree up to $7=$ Completely agree $)$. Table 4 also reveals that the mean scores (MS) of the items are very close to the median scores, ensuring that the mean score is a reliable central tendency index.

\subsection{Factor Analysis of Sustainable Food Consumption Behavior}

The 15 items measuring SFC behavior were reduced into a smaller group of items through Exploratory Factor Analysis with varimax rotation (Table 5). The analysis produced four factors $(\mathrm{KMO}=0.755 ; \mathrm{BTS}=1113.737 ; \mathrm{df}=105 ;$ Sig. $p=0.000)$, explaining $58.7 \%$ of Total Variance $(\mathrm{TV})$. The number of factors was defined with the $>1.0$ eigenvalue criteria [110], and all factor loadings exceeded the 0.4 loading criteria [111]. In the procedure, no item was dropped. Additionally, for each factor, the mean factor score (MFS) and its standard deviation (SD) was calculated, in order to use the MFS in the Gen Z cohort student's segmentation analysis.

Table 5. Derived factors of sustainable food consumption behavior.

\begin{tabular}{|c|c|c|c|c|c|}
\hline \multirow{2}{*}{ Statements } & \multicolumn{4}{|c|}{ Factors and Loading on Factor } & \multirow{2}{*}{ Communalities } \\
\hline & 1 & 2 & 3 & 4 & \\
\hline AV3 & 0.784 & & & & 0.677 \\
\hline AV1 & 0.713 & & & & 0.516 \\
\hline AV4 & 0.688 & & & & 0.556 \\
\hline AV2 & 0.610 & & & & 0.497 \\
\hline EAT3 & & 0.749 & & & 0.638 \\
\hline EAT5 & & 0.714 & & & 0.598 \\
\hline EAT4 & & 0.570 & & & 0.523 \\
\hline PUR2 & & 0.554 & & & 0.439 \\
\hline EAT2 & & 0.546 & & & 0.484 \\
\hline EAT 1 & & & 0.868 & & 0.791 \\
\hline PUR1 & & & 0.832 & & 0.731 \\
\hline PUR4 & & & 0.694 & & 0.564 \\
\hline MPS3 & & & & 0.820 & 0.679 \\
\hline MPS1 & & & & 0.712 & 0.582 \\
\hline MPS2 & & & & 0.705 & 0.532 \\
\hline Eigenvalues & 4.258 & 2.019 & 1.433 & 1.097 & \\
\hline Variance explained (\%) & 15.7 & 15.0 & 14.6 & 13.4 & \\
\hline MFS (SD) & $4.14(1.05)$ & $4.12(1.06)$ & $5.19(1.15)$ & $3.12(1.19)$ & \\
\hline Cronbach $\alpha$ of construct & 0.720 & 0.719 & 0.768 & 0.667 & \\
\hline
\end{tabular}

Source: The authors; MFS: mean factor score; SD: standard deviation; $N=252$.

The first factor is named "Restricted food", because it incorporates four statements related to avoiding purchasing and consuming food products in order to adopt an SFC behavior (MFS = 4.14; $\mathrm{SD}=1.05)$. The second factor is named "Green consumption", since it incorporates five statements that a consumer should do (eat or purchase) to adopt an SFC behavior (MFS $=4.12 ; \mathrm{SD}=1.06$ ). The third factor is called "Local consumption" because it implies purchasing from the Laikes, where the products sold are mainly seasonal, regional and sold in bulk (MFS $=5.19 ; \mathrm{SD}=1.15)$. The consumption of local foods is a very important factor in reducing the $\mathrm{CO} 2$ emissions, since local and unpackaged (in bulk) food have a low carbon footprint $[112,113]$. So the second factor refers directly to specific food products which are labeled as sustainable products, while the third relates to the food produced in the area of residence. Therefore, there is an indirect link to sustainable consumption. Lastly, the fourth factor is named "Meat and protein substitutes", incorporating three statements referring to consuming meat and protein substitutes (MFS $=3.12 ; \mathrm{SD}=1.19$ ).

\subsection{Segmentation Based on Sustainable Food Consumption Behavior Dimensions}

Subsequently, the MFS from the four dimensions extracted from factor analysis was used in segmentation analysis (research question no. 5), plus the two following variables. "People who are important to me believe that we need to have a lifestyle that is related to the sustainable consumption 
of agricultural products and food" (social norms) and "I will not buy agricultural products and food if the company that sells them is ecologically irresponsible" (ethical behavior). These two variables were entered into a cluster analysis, since previous research links these attitudes to SFC behavior [12,38-40,114-116]. Hence, we added these two variables as they help to provide a more holistic approach to the segment and respondents' behavior.

Segmentation was performed with a two-stage cluster analysis [117]. At first, hierarchical cluster analysis (Wards method) was used, providing the number of clusters as a solution, and then, K-means cluster analysis was implemented [118]. Table 6 displays the two segments derived from K-means cluster analysis, the number of participants per cluster $(N)$, and the Final Cluster Centers (FCC), and the results of the ANOVA tests (F-statistic and $p$-value). ANOVA tests (F) revealed that the two segments are different in all cases $(p<0.05)$.

Table 6. University students' segmentation based on sustainable food consumption and attitudes.

\begin{tabular}{lcccc}
\hline \multirow{2}{*}{ Factor Name/Item } & \multicolumn{2}{c}{ Final Cluster Centers } & \multicolumn{2}{c}{ ANOVA Test } \\
\cline { 2 - 5 } & $\begin{array}{c}\text { Cluster } \mathbf{1} \\
\mathbf{N = \mathbf { 1 5 3 }}\end{array}$ & $\begin{array}{c}\text { Cluster } \mathbf{2} \\
\mathbf{N}=\mathbf{9 9}\end{array}$ & $\mathbf{F}$ & $\boldsymbol{p}$ \\
\hline Restricted food & 4.58 & 3.46 & 92.055 & $<0.001$ \\
Green consumption & 4.61 & 3.36 & 124.915 & $<0.001$ \\
Local consumption & 5.44 & 4.79 & 20.888 & $<0.001$ \\
Meat and protein substitutes & 3.41 & 2.68 & 25.113 & $<0.001$ \\
SN & 4.89 & 3.51 & 81.322 & $<0.001$ \\
EB & 4.96 & 3.23 & 133.049 & $<0.001$ \\
\hline
\end{tabular}

Next, crosstabulation tests were utilized (Table 7) to explore the profile of each segment (research question no. 6).

In comparing both segments, the main differentiating power is gender (even though, in some cases, the chi-square test showed statistically-significant differences).

Segment No. 1: "The under-consideration students". This segment comprises $60.7 \%$ of the sample and is over-represented by females (65.4\%). Nineteen- and 20-year old Gen Zers are equally represented, and constitute half of the respondents, while there was a comparatively small representation of 18-year-old students. Compared to segment 2, it also has the largest percentage of the married students, as well as those from rural areas of the country, consisting of $10.5 \%$ and $25.5 \%$ of the participants of the group respectively. This segment consists of the low-income group, having more than one-third of its members coming from families with a net income/month up to 1000 euros, while no member of this group has a family income of more than 3000 euros/month. Lastly, $79.8 \%$ of this group rarely eats out and usually cooks or goes to the student restaurant to eat.

Segment No. 2: "The negatively positioned students". This group comprises of $39.3 \%$ of the sample and is over-represented by males (61.6\%). The younger Gen Z students (18 and 19 years old) constituted $43.4 \%$ of the segment, with the 18 -year olds representing $21.2 \%$. This segment, compared to the first one (the "under-consideration students"), has a slightly higher percentage of single participants, incorporates $100 \%$ of the divorced/widowed students, as well as the lowest percentage of married ones. The respondents of this group that come from cities are slightly higher than the first segment (81.8\%); they mainly come from the Region of Eastern Macedonia and Thrace $(47.5 \%)$, and have a higher family net income/month compared to "The under-consideration students" group. Lastly, $69.7 \%$ of this group usually cooks or goes to the student restaurant to eat.

Comparing the two segments, one can perceive the following: For both segments, the higher FCC is the "Local consumption" dimension with FCC $=5.44$ and FCC $=4.79$ for the first and second segment respectively. This outcome is logical, since individuals with families that reside in cities usually purchase fruit and vegetables and raw produce from the "Laikes", while those from rural areas produce them or are supplied by farmers or relatives in the area. Greeks prefer selecting their fresh products themselves, and therefore, choose to purchase products in bulk [119]. Thus, this dimension 
incorporates actions that are already in the Greek culture and are familiar to the Gen $\mathrm{Z}$ cohort; therefore, it is quite easy to apply.

Table 7. Profile of Generation Z cohort university student segments.

\begin{tabular}{|c|c|c|}
\hline \multirow{2}{*}{ Cluster Profile } & \multicolumn{2}{|c|}{ Percentages $(\%)$} \\
\hline & Cluster I & Cluster II \\
\hline \multicolumn{3}{|l|}{ Cooking pattern } \\
\hline I cook daily and never eat out & 7.2 & 6.1 \\
\hline I usually cook and rarely eat out or have food delivery & 49.7 & 39.4 \\
\hline I rarely cook and mainly I eat out or have food delivery & 9.2 & 9.1 \\
\hline I eat at the student's restaurant and I cook at home & 22.9 & 24.2 \\
\hline I eat at the student's restaurant and I eat out or have food delivery & 9.2 & 16.2 \\
\hline I never cook and I eat only gyro, pitta souvlaki, whatever is ready-made easy satiating and cheap & 2.0 & 5.1 \\
\hline \multicolumn{3}{|l|}{ Gender } \\
\hline Male & 34.6 & 61.6 \\
\hline Female & 65.4 & 38.4 \\
\hline \multicolumn{3}{|l|}{ Age } \\
\hline 18 & 9.2 & 21.2 \\
\hline 19 & 24.8 & 22.2 \\
\hline 20 & 25.5 & 15.2 \\
\hline 21 & 15.0 & 12.1 \\
\hline 22 & 20.3 & 26.3 \\
\hline 23 & 5.2 & 3.0 \\
\hline \multicolumn{3}{|l|}{ Marital status } \\
\hline Single & 89.5 & 94.9 \\
\hline Married & 10.5 & 2.0 \\
\hline Divorced/widowed & 0.0 & 3.0 \\
\hline \multicolumn{3}{|l|}{ Area of residence } \\
\hline City & 74.5 & 81.8 \\
\hline Town & 15.0 & 10.1 \\
\hline Village & 10.5 & 8.1 \\
\hline \multicolumn{3}{|l|}{ Net Monthly Family Income (in euros) } \\
\hline$\leq 1000.00$ & 35.3 & 18.2 \\
\hline $1000.01-2000.00$ & 47.1 & 58.2 \\
\hline $2000.01-3000.00$ & 17.6 & 16.2 \\
\hline$\geq 3000.01$ & 0.0 & 7.1 \\
\hline \multicolumn{3}{|l|}{ Region of residence } \\
\hline Region of Eastern Macedonia and Thrace & 34.0 & 47.5 \\
\hline Region of Central Macedonia & 20.3 & 16.2 \\
\hline Region of Attica & +12.4 & 12.1 \\
\hline Other regions of the country & 33.3 & 24.2 \\
\hline
\end{tabular}

Source: The authors; $N=252$.

On the other hand, for both segments, the dimension with the lowest FCC is the "meat and protein substitute" dimension, with FCC $=3.41$ and FCC $=2.68$ for the first and second segment respectively. While researchers consider that the key to SFC is reducing meat consumption $[120,121]$, today modern Greek people consider meat consumption as part of their usual consumption pattern. Karagiannis and Velentzas [122] pointed out that from 1950-1993, Greeks budget share of meat increased by almost three times. Lazaridis [123] quotes "One of the most striking changes in food demand in Greece over the past few decades has been the increase in meat consumption. In 1960, the country spent $14.5 \%$ of its total food expenditure on meat. By 1983, this increased to $30 \% "$. This is in line with the findings of many researchers who found that Greeks have moved away from the Mediterranean diet, due to socio-economic and lifestyle changes [124]. As for meat substitution, this could be implemented in many ways, though, as for insect consumption, this was rejected by the Gen Z cohort students, which is logical, since it is distinct from the Greek mentality and food culture. The Mediterranean diet is based on low meat consumption (about once per week). While meat substitutes from plants such as the use of soya is something relatively new (after 1986) in the Greek food culture [125], other substitutes of meat and proteins are used. Some of the most popular are the "fakorizo" (lentils with rice) and "revithorizo" (chickpeas with rice), which are meat substitutes that are even today commonly used during fasting. There is a probability that Gen $\mathrm{Z}$ students are not aware of the variety of substitutes that they may encounter regarding meat consumption and dairy products. 
Both segments have an over-representation of Gen $\mathrm{Z}$ students that come from cities. While preceding studies have identified that the sustainable consumer segments consisted of people from urban areas, this study found the opposite. This study identified that the Gen Z cohort students from cities do not have SFC behavior. One probable cause could be that young people living permanently in the cities come into contact less often with nature than with those who live in rural areas, and so are probably less sensitive to the environmental issues, especially in their youth [126].

A closer observation of the segments, reveals that for segment No. 1, the Gen Z students cannot be considered to follow an SFC behavior, since no FCC of this segment is $>5.51$. This contrasts the "The negatively positioned students", on the grounds that even though they have not adopted an SFC behavior, they will consider it for the future. As for the first dimension "Restricted food", this group, although it does not incorporate in its behavior the food restrictions recommended for SFC, is positively predisposed to think about it and apply it in the future $(\mathrm{FCC}=4.58)$. As for the second dimension, "Green consumption", which is linked to direct sustainable eating behavior, again, this group does not, in essence, apply it at the moment but is willing to think about it in the future, with a tendency to "eat green" whenever possible (FCC $=4.61)$. The most positive SFC behavior is towards the dimension "Local consumption" (FCC $=5.44)$. This segment occasionally (whenever they can) functions in this way. This is considered logical, since individuals in this group come from rural areas, where the supplied products are mostly local, seasonal and in bulk form, and that is the way they have learned to eat in their childhood. As regards the social norms dimension, it reveals that people that are close and important to the participants tend to slightly agree $(\mathrm{FCC}=4.89)$ that they should have a lifestyle that is related to the sustainable consumption of agricultural products and food. This confirms that their "people of interest" and "influencers" are not people with "strong" SFC behavior either. As for the ethical behavior dimension, participants in this segment tend to slightly agree that they will not buy agricultural products and food if the company that sells them is ecologically irresponsible $(\mathrm{FCC}=4.96)$.

Different reasons justify this segments' behavior. One reason could be that it possesses a higher percentage of females. Females are more sensitive compared to males in sustainable consumption issues, as previous research has revealed [82,127]. The same is for married people, who tend to purchase sustainable products more frequently [128] and care more about the nutrition patterns of the food products [129]. These findings are also in line with Seyrek and Gul [130] who, in their study regarding green purchasing behavior, found that married participants presented more green purchasing behavior than single participants. Moreover, they care more about environmental and ethical issues. Probably, family creation and the responsibility of a baby makes them more interested in food attributes, as well as the future of the environment. Lastly, as opposed to other studies that found that individuals from urban areas are more environmentally sensitive, this segment, of which one-fourth comprises people from rural areas, has higher SFC behavior. This could be due to the fact that they are from rural areas, and therefore, they have somewhat higher sensitivity to environmental issues and production methods compared to people who live in cities. This is justified on the basis that they usually consume what they produce, or that friends and relatives may provide them with different agricultural fresh and food products.

In consideration of the fact that in all cases except the meat and protein substitute dimension the members of this group do not hold negative attitudes towards SFC behavior, this group may acquire SFC behavior in the future. This could be accomplished by raising awareness of the benefits of following a SFC lifestyle, not only for the environment and for their health, but the future generations too. The latter is of particular interest because of the gender composition of the segment, which is overrepresented by females, and thus, may be more sensitive to the "future generation" appeals due to subsequent motherhood. Additionally, this awareness campaign should focus not only on the members of this group, but to their influencers too, to obtain the best and quickest results.

The No. 2 segment overall has significantly lower FCC than the segment No.1. In general, these university students are not even thinking about adopting an SFC behavior soon. As regards the 
dimensions "Restricted food", "Green consumption" and "Meat and protein substitutes" the FCC's in all cases are $<3.50$. The only FCC considered as high is the "Local consumption" dimension (FCC = 4.79), which was somewhat comparable with the "under-consideration students" group (FCC = 5.44).

The above behavior can be justified based on several arguments. One could be that this group of Gen Z students consists mainly of men (61.6\%), and men are less prone to environmental interest than women [42,131]. Additionally, about the half members of this group belong in the younger Gen Zers, i.e., 18 and 19 years old. Young people, and especially single young people, are not so interested in food nutrition patterns, probably because of the low level of health problems that this age encounters. This is justified by Tripathi [132], who states that people tend to be more health conscious when aging. Also, Seyrek and Gul [130] in their study found that consumers age and marital status affect their green purchasing behavior. Specifically, they found that young and single participants present less green purchasing behavior compared to married and older ones. Also, previous research revealed that segments that are not considered green consumers are mostly composed of young participants [131]. In addition, since this group of young students has higher family incomes, they could be more materialistic and care more about pleasure and self-satisfaction than the "greater good", especially when it has to do with the future. Ivy et al. [133] found that young people have strongly positive attitudes toward environmental concerns, as long as these concerns do not "have a direct bearing on their lives". Lastly, as regards consuming meat and protein substitutes, this group is reluctant to consider it, even in the future. This could be due to the fact that it mainly consists of males compared to females, and previous research has found that these two items are related, specifically, meat consumption is associated with masculinity and power [134]. As concerns the social norms dimension, it seems true to say that people that are important to this Gen Z student segment do not exercise SFC behavior, and therefore, disagree that Gen $Z$ students should have a lifestyle that is related to the sustainable consumption of agricultural products and food (FCC $=3.51$ ). Previous research confirms that subjective (or social) norms, as well as reference groups, influence individuals' green purchasing behavior [35]. The Generation $\mathrm{Z}$ cohort consumers are strongly influenced in their purchasing decisions by peer contact [135], while Vermeir and Verbeke [12] found that the participants in their study did not strongly perceive that friends or family want them to buy sustainable products. Moreover, the members of this group are not willing to change the point of purchase of products if the provider shows ecologically irresponsible behavior $(F C C=3.23)$. Tilikidou and Delistaurou [136] found that Greeks are seldom involved in actual ethical preferences, and state that ethical consumption is still in its infancy in Greece. They also found that Greek consumers seldom take part in boycotting actions.

Overall, it seems that Greek university students that participated in the research do not tend to have a SFC behavior after leaving home and living on their own. These findings are similar with previous works focusing on university students from various countries, including Greece, which found that the possibility of making unhealthy food choices is more probable for university students living away from home than those living with their families $[57,137]$. Also, the results mentioned above suggest that the segments derived from this study share some common attitudes with the "potentially sustainable food consumer" and the "inattentive food consumer" segments of Vecchio and Annunziata's [77] study. One explanation might be that both samples of university students are close in terms of age and Mediterranean mentality. It is also partially in agreement with the study of Forleo et al. [138], and specifically, with the "unconcerned group", which consisted mostly of undergraduate students. However, the present study has found the opposite results to the Kyrkou et al. [139] study, who researched the dietary patterns of 405 university students enrolled in the Agricultural Science Faculty of the Aristotle University of Thessaloniki. They compared eating patterns of students in $2006(n=242)$ and $2016(n=163)$. Contrary to this study, they found that students' dietary habits have been modified, and are better compared to those recorded in 2006, with higher levels of consumption of several plant-based foods. The reasons for this change, according to the researchers, are budgetary constraints, increasing nutritional awareness and other socio-cultural factors characterizing the students. 


\section{Conclusions}

In-depth knowledge of SFC behavior regarding university students, and especially younger ones, reveals tendencies of the worlds' sustainable future. Previous studies have advanced our knowledge of SFC from many points of views, and have indicated the importance of this group to be targeted and studied regarding their sustainable behavior.

This study aims to explore the SFC behavior of the Gen Z cohort that is studying in Greek universities and living away from home, answering six research questions. From a theoretical point of view, our study contributes to the existing literature by providing empirical evidence from the Gen $\mathrm{Z}$ cohort where a dearth of studies in the marketing field is observed. To the author's knowledge, this is the first study dealing with the segmentation of university students belonging in the Gen $\mathrm{Z}$ cohort and SFC behavior, and thus, it contributes to the literature on SFC, as well as the to the generational cohort research.

In studying the SFC behavior of this group, the results clearly show that the focus of SFC is essentially limited to eating seasonal fruits and vegetables and purchasing regional food. This study also revealed that university students as a group do not have homogeneous SFC behavior. It identified two students' segments based on SFC behavior, social norms and ethical behavior, namely the "The under-consideration students" and "The negatively positioned students", revealing that there is no segment that encompasses a lifestyle of SFC, but the first and larger segment is more positively predisposed towards it, and is thus willing to think about it in the future. From the marketing point of view, these two segments may lead marketers to approach each group differently, based on their behavior. An example is that marketing managers need to focus on consumers who have already created or think about the creation of a family. People at this stage are more sensitive to the consumption of food products. They also need to promote local food products and invest in the development of marketing channels. Local farm markets, for example, are an opportunity for marketers to promote food products, and in this way decrease the number of distribution channels. Furthermore, according to the results, they need to invest in products that are close to the Mediterranean diet and are familiar to consumers, since they are not willing to adopt dietary patterns from other cultures that are very distinct of their own culture. People consume food products with which they are familiar, so marketers need to respect the culinary culture and tradition of the consumers. Moreover, marketers and policymakers need to invest in the education of consumers on sustainability issues. Information about sustainability issues should be a part of the labeling and branding strategy.

As for practical implications, the results of the current study may be drivers for public policy and marketing interventions for motivating SFC behavior, and should be taken into account in order for a sustainable future of the country to be developed. Specifically, the government and its policymakers should be aware that the youths of the country do not really engage in SFC behavior, and therefore, should develop initiatives for changing behavior. In this vein, curriculums should be applied at school regarding not only energy saving, but also courses referring to SFC, sustainable diets and their benefits for individuals and society as a whole. University restaurants also should have more sustainable choices regarding the food provided to students. Furthermore, the government, through its respective institutions (i.e., ministry of education), can offer relevant information and design promotional campaigns in the universities to increase the students' awareness on SFC and to promote SFC. Since peer pressure and reference groups has been shown to influence behavior, SFC changes have to target a broader age range, such as parents and peers. Hence, social marketing campaigns could be implemented in order to promote SFC awareness to all parties of interest.

\section{Limitations of the Study and Directions for Further Research}

This research has various limitations, some of which may be considered as directions for future research. One limitation has to do with the targeted sample of the research. This study deals with university students of the Generation $\mathrm{Z}$ cohort. This restricts generalizations of findings to other university students, as well as to other generational cohorts in Greece. Additional limitations derive 
from the limited number of participants, combined with the sampling method for data collection. Due to time and money constraints (this research was self-funded), a non-probability sampling method was applied, and online data collection was implemented. Thus, the generalizability of results is restricted. Another limitation comes from the items used to measure SFC behavior. Fifteen items were used, of which twelve were derived from previous studies, and three from qualitative research. Other items that are equally important could be added for studying SFC behavior. Moreover, this research did not deal with the reasons for rejecting more SFC behaviors, which are of great interest for policymakers. Even though this research has the above limitations, it is considered of importance, since it provides insight about the SFC behavior of the youngest adult Greek consumers, the Generation Z cohort and future family providers, an issue with extreme scarcity of studies, and with great future marketing challenges.

Future works could include more generational cohorts in order to verify the applicability of the current segments and to provide a complete picture regarding the SFC patterns. In addition, further research could verify and extend these findings by employing larger and more representative samples and take into consideration other factors that might influence SFC. Other studies could explore the young university student group as food decision makers in their own family before moving away to study, as they might experience different food consumption patterns.

Author Contributions: Conceptualization of research and design, I.C.K.; Formal analysis, I.C.K. and S.A.M.; Investigation, I.C.K., S.A.M., S.P. and E.-Z.G.B.; Methodology, I.C.K. and S.A.M.; Project administration, I.C.K. and S.A.M.; Writing—original draft, S.P. and E.-Z.G.B.; Writing—review and editing, I.C.K. and S.A.M.

Funding: This research received no external funding.

Acknowledgments: We would like to thank the reviewers for their constructive comments.

Conflicts of Interest: The authors declare no conflict of interest.

\section{References}

1. Duchin, F. Sustainable consumption of food: A framework for analyzing scenarios about changes in diets. J. Ind. Ecol. 2005, 9, 99-114. [CrossRef]

2. Foltz, J.C.; Lee, J.G.; Martin, M.A.; Preckel, P.V. Multiattribute assessment of alternative cropping systems. Am. J. Agric. Econ. 1995, 77, 408-420. [CrossRef]

3. Bacon, L.; Krpan, D. (Not) Eating for the environment: The impact of restaurant menu design on vegetarian food choice. Appetite 2018, 125, 190-200. [CrossRef] [PubMed]

4. Reisch, L.; Eberle, U.; Lorek, S. Sustainable food consumption: An overview of contemporary issues and policies. Sustain. Sci. Pract. Policy 2013, 9, 7-25. [CrossRef]

5. Van Dooren, C.; Marinussen, M.; Blonk, H.; Aiking, H.; Vellinga, P. Exploring dietary guidelines based on ecological and nutritional values: A comparison of six dietary patterns. Food Policy 2014, 44, 36-46. [CrossRef]

6. Redman, E.; Redman, A. Transforming sustainable food and waste behaviors by realigning domains of knowledge in our education system. J. Clean. Prod. 2014, 64, 147-157. [CrossRef]

7. Carlsson-Kanyama, A.; González, A.D. Potential contributions of food consumption patterns to climate change. Am. J. Clin. Nutr. 2009, 89, 1704S-1709S. [CrossRef] [PubMed]

8. Lorenz, B.A.; Langen, N. Determinants of how individuals choose, eat and waste: Providing common ground to enhance sustainable food consumption out-of-home. Intern. J. Consum. Stud. 2018, 42, 35-75. [CrossRef]

9. Thøgersen, J. Sustainable food consumption in the nexus between national context and private lifestyle: A multi-level study. Food Qual. Preference 2017, 55, 16-25. [CrossRef]

10. Hoek, A.C.; Pearson, D.; James, S.W.; Lawrence, M.A.; Friel, S. Healthy and environmentally sustainable food choices: Consumer responses to point-of-purchase actions. Food Qual. Preference 2017, 58, 94-106. [CrossRef]

11. Vanhonacker, F.; Van Loo, E.J.; Gellynck, X.; Verbeke, W. Flemish consumer attitudes towards more sustainable food choices. Appetite 2013, 62, 7-16. [CrossRef] [PubMed] 
12. Vermeir, I.; Verbeke, W. Sustainable food consumption: Exploring the consumer attitude-Behaviour gap. J. Agric. Environ. Ethics 2006, 19, 169-194. [CrossRef]

13. Annunziata, A.; Scarpato, D. Factors affecting consumer attitudes towards food products with sustainable attributes. Agric. Econ. Zemedelska Ekonomika 2014, 60, 353-363. [CrossRef]

14. FAO. Definition of sustainable diets. Food and Agriculture Organization of the United Nations. Presented at International Scientific Symposium: Biodiversity and Sustainable Diets United Against Hunger, Rome, Italy, 3-5 November 2010. Available online: http://www.fao.org/ag/humannutrition/285070e8d8dc364ee46865d5841c48976e9980.pdf (accessed on 26 July 2018).

15. Verain, M.C.; Bartels, J.; Dagevos, H.; Sijtsema, S.J.; Onwezen, M.C.; Antonides, G. Segments of sustainable food consumers: A literature review. Int. J. Consum. Stud. 2012, 36, 123-132. [CrossRef]

16. Clarke, N.; Barnett, C.; Cloke, P.; Malpass, A. The political rationalities of fair-trade consumption in the United Kingdom. Politics Soc. 2007, 35, 583-607. [CrossRef]

17. Tanner, C.; Wölfing Kast, S. Promoting sustainable consumption: Determinants of green purchases by Swiss consumers. Psychol. Mark. 2003, 20, 883-902. [CrossRef]

18. Miranda-de la Lama, G.C.; Estévez-Moreno, L.X.; Villarroel, M.; Rayas-Amor, A.A.; María, G.A.; Sepúlveda, W.S. Consumer attitudes toward animal welfare-friendly products and willingness to pay: Exploration of Mexican market segments. J. Appl. Anim. Welf. Sci. 2018, 1-13. [CrossRef]

19. De Bakker, E.; Dagevos, H. Reducing meat consumption in today's consumer society: Questioning the citizen-consumer gap. J. Agric. Environ. Ethics 2012, 25, 877-894. [CrossRef]

20. Clonan, A.; Holdsworth, M.; Swift, J.; Wilson, P. UK consumers' priorities for sustainable food purchases. In Proceedings of the 84th Annual Conference of the Agricultural Economics Society, Edinburgh, UK, 29-31 March 2010. Available online: https:/ / www.researchgate.net/profile/Michelle_Holdsworth/publication/ 46471682_UK_Consumers_Priorities_for_Sustainable_Food_Purchases/links /09e4150fe7b090e1ee000000. pdf (accessed on 20 December 2018).

21. Hartikainen, H.; Roininen, T.; Katajajuuri, J.M.; Pulkkinen, H. Finnish consumer perceptions of carbon footprints and carbon labelling of food products. J. Clean. Prod. 2014, 73, 285-293. [CrossRef]

22. Page, G.; Ridoutt, B.; Bellotti, B. Carbon and water footprint tradeoffs in fresh tomato production. J. Clean. Prod. 2012, 32, 219-226. [CrossRef]

23. Iribarren, D.; Hospido, A.; Moreira, M.T.; Feijoo, G. Carbon footprint of canned mussels from a business-to-consumer approach. A starting point for mussel processors and policy makers. Environ. Sci. Policy 2010, 13, 509-521. [CrossRef]

24. Vainio, A.; Niva, M.; Jallinoja, P.; Latvala, T. From beef to beans: Eating motives and the replacement of animal proteins with plant proteins among Finnish consumers. Appetite 2016, 106, 92-100. [CrossRef]

25. Clonan, A.; Wilson, P.; Swift, J.A.; Leibovici, D.G.; Holdsworth, M. Red and processed meat consumption and purchasing behaviours and attitudes: Impacts for human health, animal welfare and environmental sustainability. Public Health Nutr. 2015, 18, 2446-2456. [CrossRef] [PubMed]

26. Scalvedi, M.L.; Saba, A. Exploring local and organic food consumption in a holistic sustainability view. Br. Food J. 2018, 120, 749-762. [CrossRef]

27. Feldmann, C.; Hamm, U. Consumers' perceptions and preferences for local food: A review. Food Qual. Preference 2015, 40, 152-164. [CrossRef]

28. Arsil, P.; Li, E.; Bruwer, J.; Lyons, G. Exploring consumer motivations towards buying local fresh food products: A means-end chain approach. Br. Food J. 2014, 116, 1533-1549. [CrossRef]

29. Onozaka, Y.; Nurse, G.; McFadden, D.T. Local food consumers: How motivations and perceptions translate to buying behavior. Choices 2010, 25, 1-6.

30. Vitters $\varnothing$, G.; Tangeland, T. The role of consumers in transitions towards sustainable food consumption. The case of organic food in Norway. J. Clean. Prod. 2015, 92, 91-99. [CrossRef]

31. Thøgersen, J.Q. Country differences in sustainable consumption: The case of organic food. J. Macromark. 2010, 30, 171-185. [CrossRef]

32. Song, G.; Li, M.; Semakula, H.M.; Zhang, S. Food consumption and waste and the embedded carbon, water and ecological footprints of households in China. Sci. Total Environ. 2015, 529, 191-197. [CrossRef]

33. Clemente, G.; Pérez-Sánchez, M.; Ribal, J.; Sanjuán, N.; Escobar, N. Influence of agro-food waste on sustainable food consumption. In Proceedings of the 6th International Conference on Life Cycle Management, Gothenburg, Sweden, 25-28 August 2013. 
34. Wang, P.; Liu, Q.; Qi, Y. Factors influencing sustainable consumption behaviors: A survey of the rural residents in China. J. Clean. Prod. 2014, 63, 52-165. [CrossRef]

35. Salazar, H.A.; Oerlemans, L.; van Stroe-Biezen, S. Social influence on sustainable consumption: Evidence from a behavioural experiment. Int. J. Consum. Stud. 2013, 37, 172-180. [CrossRef]

36. Pickett-Baker, J.; Ozaki, R. Pro-environmental products: Marketing influence on consumer purchase decision. J. Consum. Mark. 2008, 25, 281-293. [CrossRef]

37. Jackson, T. Motivating sustainable consumption. Sustain. Dev. Res. Netw. 2005, 29, 30.

38. Zagata, L. Consumers' beliefs and behavioural intentions towards organic food. Evidence from the Czech Republic. Appetite 2012, 59, 81-89. [CrossRef]

39. De Maya, S.R.; López-López, I.; Munuera, J.L. Organic food consumption in Europe: International segmentation based on value system differences. Ecol. Econ. 2011, 70, 1767-1775. [CrossRef]

40. Richter, I.; Klöckner, C. The psychology of sustainable seafood consumption: A comprehensive approach. Foods 2017, 6, 86. [CrossRef]

41. Akehurst, G.; Afonso, C.; Martins Gonçalves, H. Re-examining green purchase behaviour and the green consumer profile: New evidences. Manag. Decis. 2012, 50, 972-988. [CrossRef]

42. Diamantopoulos, A.; Schlegelmilch, B.B.; Sinkovics, R.R.; Bohlen, G.M. Can socio-demographics still play a role in profiling green consumers? A review of the evidence and an empirical investigation. J. Bus. Res. 2003, 56, 465-480. [CrossRef]

43. Straughan, R.D.; Roberts, J.A. Environmental segmentation alternatives: A look at green consumer behavior in the new millennium. J. Consum. Mark. 1999, 16, 558-575. [CrossRef]

44. Luthra, S.; Garg, D.; Haleem, A. An analysis of interactions among critical success factors to implement green supply chain management towards sustainability: An Indian perspective. Resour. Policy 2015, 46, 37-50. [CrossRef]

45. Luthra, S.; Mangla, S.K.; Xu, L.; Diabat, A. Using AHP to evaluate barriers in adopting sustainable consumption and production initiatives in a supply chain. Int. J. Prod. Econ. 2016, 181, 342-349. [CrossRef]

46. Robinson, R.; Smith, C. Psychosocial and demographic variables associated with consumer intention to purchase sustainable produced foods as defined by the midwest food alliance. J. Nutr. Educ. Behav. 2002, 34, 316-325. [CrossRef]

47. Niva, M.; Mäkelä, J.; Kahma, N.; Kjærnes, U. Eating sustainably? Practices and background factors of ecological food consumption in four Nordic countries. J. Consum. Policy 2014, 37, 465-484. [CrossRef]

48. Verain, M.C.; Sijtsema, S.J.; Antonides, G. Consumer segmentation based on food-category attribute importance: The relation with healthiness and sustainability perceptions. Food Qual. Preference 2016, 48, 99-106. [CrossRef]

49. Vermeir, I.; Verbeke, W. Sustainable food consumption among young adults in Belgium: Theory of planned behaviour and the role of confidence and values. Ecol. Econ. 2008, 64, 542-553. [CrossRef]

50. Eastman, J.K.; Iyer, R.; Thomas, S.P. The impact of status consumption on shopping styles: An exploratory look at the millennial generation. Mark. Manag. J. 2013, 23, 57-73.

51. Williams, K.C.; Page, R.A. Marketing to the generations. J. Behav. Stud. Bus. 2011, 3, 1-17.

52. Meredith, G.E.; Schewe, C.D.; Karlovich, J. Defining Markets, Defining Moments: America's 7 Generational Cohorts, Their Shared Experiences, and Why Businesses Should Care; John Wiley \& Sons: New York, NY, USA, 2002.

53. Mannheim, K. The problem of generations. In Karl Mannheim: Essays; Kecskemeti, P., Ed.; Routledge: London, UK, 1952; pp. 276-322.

54. Kamenidou, I.C.; Mamalis, S.A.; Dimitriadis, E. Generation Z perceptions of quality certification: A cross-national study. Int. J. Food Beverage Manuf. Bus. Mod. 2018, 3, 23-41. [CrossRef]

55. Abraham, S.; Noriega, B.R.; Shin, J.Y. College students eating habits and knowledge of nutritional requirements. J. Nutr. Hum. Health 2018, 2, 13-17.

56. Bagordo, F.; Grassi, T.; Serio, F.; Idolo, A.; De Donno, A. Dietary habits and health among university students living at or away from home in southern Italy. J. Food Nutr. Res. 2013, 52, 164-171.

57. Kremmyda, L.S.; Papadaki, A.; Hondros, G.; Kapsokefalou, M.; Scott, J.A. Differentiating between the effect of rapid dietary acculturation and the effect of living away from home for the first time, on the diets of Greek students studying in Glasgow. Appetite 2008, 50, 455-463. [CrossRef] 
58. Zhu, Q.; Li, Y.; Geng, Y.; Qi, Y. Green food consumption intention, behaviors and influencing factors among Chinese consumers. Food Qual. Preference 2013, 28, 279-286. [CrossRef]

59. Zeng, Y.; Xia, W.; Huang, B. The consumer consciousness and corresponding influencing factors for green purchasing based on the analysis of consumer survey in Beijing. Consum. Econ. 2007, 23, 38-42.

60. Mensink, G.; Barbosa, C.L.; Brettschneider, A.K. Prevalence of persons following a vegetarian diet in Germany. J. Health Monit. 2016, 1. [CrossRef]

61. Aguirre, J.A. The farmer's market organic consumer of Costa Rica. Br. Food J. 2007, 109, 145-154. [CrossRef]

62. Arvanitoyannis, I.S.; Krystallis, A.; Kapirti, A. Health and environmental consciousness. J. Int. Food Agribus. Mark. 2004, 15, 93-136. [CrossRef]

63. Vantamay, N. Investigation and recommendations on the promotion of sustainable consumption behavior among young consumers in Thailand. Kasetsart J. Soc. Sci. 2018, 39, 51-58. [CrossRef]

64. Priporas, C.-V.; Stylos, N.; Fotiadis, A.K. Generation Z consumers' expectations of interactions in smart retailing: A future agenda. Comp. Hum Behav. 2017, 77, 374-381. [CrossRef]

65. Tifferet, S.; Rosenblit, N.; Shalev, M. Promoting sustainability in a college café by opposite-sex cashiers. Int. J. Sustain. High. Educ. 2017, 18, 1279-1290. [CrossRef]

66. Fiala, J.; Toufarová, I.; Mokrý, S.; Souček, M. Perception of local food labelling by generation Z: An eye-tracking experiment. Eur. J. Bus. Sci. Technol. 2016, 2, 152-159. [CrossRef]

67. Bogueva, D.; Schmidinger, K. Normality, Naturalness, Necessity, and Nutritiousness of the New Meat Alternatives. In Environmental, Health, and Business Opportunities in the New Meat Alternatives Market; IGI Global: Hershey, PA, USA, 2019; pp. 20-37.

68. Beretzky, Z.; Jámbor, Z. Are young Z generation members really in danger? Nutrition habits of Hungarian students. In Some Recent Research from Economics and Business Studies; Karlovitz, T.J., Ed.; International Research Institute sro: Komárno, Slovakia, 2018; pp. 127-138. Available online: http:/ /www.irisro.org/ economics2018january/34BeretzkyZsuzsanna-JamborZsofia.pdf (accessed on 13 December 2018).

69. Rana, J.; Paul, J. Consumer behavior and purchase intention for organic food: A review and research agenda. J. Retail. Consum. Serv. 2017, 38, 157-165. [CrossRef]

70. Činčera, J.; Stejskal, J.; Mach, M.; Lupač, M. Organic food is fertilised at night: Why people (do not) buy environmentally friendly products. Envigogika 2018, 9. Available online: http:/ / www.envigogika.cuni.cz/ (accessed on 23 December 2018). [CrossRef]

71. Ede, J.; Graine, S.; Rhodes, C. Moving Towards Sustainable Food Consumption: Identifying Barriers to Sustainable Student Diets. Master's Thesis, School of Engineering, Blekinge Institute of Technology, Karlskrona, Sweden, 2011.

72. Savelli, E.; Murmura, F.; Liberatore, L.; Casolani, N.; Bravi, L. Consumer attitude and behaviour towards food quality among the young ones: Empirical evidences from a survey. Total Qual. Manag. Bus. Excell. 2019, 1-15. [CrossRef]

73. Deliens, T.; Clarys, P.; De Bourdeaudhuij, I.; Deforche, B. Determinants of eating behaviour in university students: A qualitative study using focus group discussions. BMC Public Health 2014, 14, 53. [CrossRef]

74. De Groeve, B.; Bleys, B. Less meat initiatives at Ghent University: Assessing the support among students and how to increase it. Sustainability 2017, 9, 1550. [CrossRef]

75. Ahamad, N.R.; Ariffin, M. Assessment of knowledge, attitude and practice towards sustainable consumption among university students in Selangor, Malaysia. Sustain. Prod. Consum. 2018, 16, 88-98. [CrossRef]

76. Annunziata, A.; Mariani, A.; Vecchio, R. Effectiveness of sustainability labels in guiding food choices: Analysis of visibility and understanding among young adults. Sustain. Prod. Consum. 2019, 17, 108-115. [CrossRef]

77. Vecchio, R.; Annunziata, A. Consumers' attitudes towards sustainable food: A cluster analysis of Italian university students. New Medit 2013, 12, 47-56.

78. Aprile, M.C.; Mariani, A. Young people's propensity to use sustainability labels on food products: A case study in the South of Italy. Calitatea 2015, 16, 75-79.

79. Tobler, C.; Visschers, V.H.; Siegrist, M. Eating green. Consumers' willingness to adopt ecological food consumption behaviors. Appetite 2011, 57, 674-682. [CrossRef]

80. Lindeman, M.; Väänänen, M. Measurement of ethical food choice motives. Appetite 2000, 34, 55-59. [CrossRef] 
81. Aarnio, K.; Lindeman, M. Magical food and health beliefs: A portrait of believers and functions of the beliefs. Appetite 2004, 43, 65-74. [CrossRef]

82. Roberts, J.A. Green consumers in the 1990s: Profile and implications for advertising. J. Bus. Res. 1996, 36, 217-231. [CrossRef]

83. Patton, M.Q. Qualitative Evaluation and Research Methods; Sage: London, UK, 1990.

84. Creswell, J.W.; Miller, D.L. Determining validity in qualitative inquiry. Theory Pract. 2000, 39, $124-130$. [CrossRef]

85. Kent, R. Marketing Research in Action; Routledge: London, UK, 1993.

86. Chon, K.S. Consumer Satisfaction and Dissatisfaction in Tourism as Related to Destination Image Perception. Ph.D. Thesis, Virginia Polytechnic Institute and State University, Blacksburg, VA, USA, 1990.

87. Priporas, C.V.; Kamenidou, I.; Kapoulas, A.; Papadopoulou, F.M. Counterfeit purchase typologies during an economic crisis. Eur. Bus. Rev. 2015, 27, 2-16. [CrossRef]

88. Spector, P.E. Summated Rating Scale Construction: An Introduction, Sage University Paper Series No.82, on Quantitative Applications in the Social Sciences; Sage: Beverly Hills, CA, USA, 1992.

89. Fornell, C.; Larcker, D.F. Evaluating structural equation models with unobservable variables and measurement error. J. Mark. Res. 1981, 18, 39-50. [CrossRef]

90. Sogari, G.; Velez-Argumedo, C.; Gómez, M.; Mora, C. College students and eating habits: A study using an ecological model for healthy behavior. Nutrients 2018, 10, 1823. [CrossRef]

91. Lionis, C.; Kafatos, A.; Vlachonikolis, G.; Vakaki, M.; Tzortzi, M.; Petraki, A. The effects of a health education intervention programme among Cretan adolescents. Prev. Med. 1991, 20, 685-699. [CrossRef]

92. Karampola, M.; Papandreou, D.; Makedou, K. The role of Mediterranean diet in health and disease: An updated mini review. Nutr. Food Sci. 2011, 41, 63-72. [CrossRef]

93. Trichopoulou, A.; Costacou, T.; Bamia, C.; Trichopoulou, D. Adherence to the Mediterranean diet and survival in a Greek population. N. Engl. J. Med. 2003, 348, 2599-2608. [CrossRef]

94. Curtis, B.M.; O'Keefe, J.H., Jr. Understanding the Mediterranean diet: Could this be the new "gold standard" for heart disease prevention? Postgrad. Med. 2002, 112, 35-45. [CrossRef]

95. Pairotti, M.B.; Cerutti, A.K.; Martini, F.; Vesce, E.; Padovan, D.; Beltramo, R. Energy consumption and GHG emission of the Mediterranean diet: A systemic assessment using a hybrid LCA-IO method. J. Clean. Prod. 2015, 103, 507-516. [CrossRef]

96. Wang, L.; Wang, J.; Huo, X. Consumer's Willingness to Pay a Premium for Organic Fruits in China: A Double-Hurdle Analysis. Int. J. Environ. Res. Public Health 2019, 16, 126. [CrossRef]

97. Kyriakopoulos, K.; van Dijk, G. Post-purchase intentions for organic foodstuff: A conceptual framework based on the perception of product value. J. Int. Food Agribus. Mark. 1997, 9, 1-19. [CrossRef]

98. Zavali, M.; Theodoropoulou, H. Investigating determinants of green consumption: Evidence from Greece. Soc. Responsib. J. 2018, 14, 719-736. [CrossRef]

99. Amvrosiou, A.; Theodoropoulou, E.; Mitoula, R. The Study of the Attitudes and Perceptions of Modern Greeks during the Economic Crisis on the Consumption of Organic Products. Int. Rev. Soc. Sci. 2017, 5, 625-635.

100. Sametz, R.; Maydoney, A. Storytelling through design. Des. Manag. J. 2003, 14, 18-34. [CrossRef]

101. Hultén, B. Branding by the five senses: A sensory branding framework. J. Brand Strategy 2017, 6, $281-292$.

102. Conti, C.; Costa, A.; Balzaretti, C.; Russo, V.; Tedesco, D. Survey on food preferences of university students: From tradition to new food customs? Agriculture 2018, 8, 155. [CrossRef]

103. Verbeke, W. Profiling consumers who are ready to adopt insects as a meat substitute in a Western society. Food. Qual. Preference 2015, 39, 147-155. [CrossRef]

104. Hartmann, C.; Shi, J.; Giusto, A.; Siegrist, M. The psychology of eating insects: A cross-cultural comparison between Germany and China. Food Qual. Preference 2015, 44, 148-156. [CrossRef]

105. Lapinski, M.K.; Rimal, R.N. An explication of social norms. Commun. Theory 2005, 15, 127-147. [CrossRef]

106. Higgs, S.; Thomas, J. Social influences on eating. Curr. Opin. Behav. Sci. 2016, 9, 1-6. [CrossRef]

107. Broadbent, E.; Gougoulis, J.; Lui, N.; Pota, V.; Simons, J. Generation Z: Global Citizenship Survey. What the World's Young People Think and Feel, Varkey Foundation. 2017, pp. 26-44. Available online: http:/ / knowledge4all.com/Temp/Files/f905c620-6d2b-4938-96cd-9f5d8373815c.pdf (accessed on 12 December 2018). 
108. Szmigin, I.; Carrigan, M.; McEachern, M. The conscious consumer: Taking a flexible approach to ethical behavior. Int. J. Consum. Stud. 2009, 33, 224-231. [CrossRef]

109. Cooper-Martin, E.; Holbrook, M.B. Ethical Consumption Experiences and Ethical Space. Adv. Consum. Res. 1993, 20, 113-118.

110. Kaiser, H.F. The varimax criterion for analytic rotation in factor analysis. Psychometrika 1958, 23, $187-200$. [CrossRef]

111. Ford, J.K.; MacCallum, R.C.; Tait, M. The application of exploratory factor analysis in applied psychology: A critical review and analysis. Pers. Psychol. 1986, 39, 291-314. [CrossRef]

112. Coley, D.; Howard, M.; Winter, M. Local food, food miles and carbon emissions: A comparison of farm shop and mass distribution approaches. Food Policy 2009, 34, 150-155. [CrossRef]

113. Guirong, Z.; Junli, L.; Dehua, L.; Zhiping, W. Study on Green Logistics and Sustainable Development. In Proceedings of the 2010 International Conference on Optoelectronics and Image Processing (ICOIP), Haikou, China, 11-12 November 2010; Volume 2, pp. 431-434. [CrossRef]

114. Honkanen, P.; Verplanken, B.; Olsen, S.O. Ethical values and motives driving organic food choice. J. Consum. Behav. Int. Res. Rev. 2006, 5, 420-430. [CrossRef]

115. Torjusen, H.; Lieblein, G.; Wandel, M.; Francis, C.A. Food system orientation and quality perception among consumers and producers of organic food in Hedmark County, Norway. Food Qual. Preference 2001, 12, 207-216. [CrossRef]

116. Grunert, S.C.; Juhl, H.J. Values, environmental attitudes, and buying of organic foods. J. Econ. Psychol. 1995, 16, 39-62. [CrossRef]

117. Punj, G.; Stewart, D.W. Cluster analysis in marketing research: Review and suggestions for application. J. Mark. Res. 1983, 20, 134-148. [CrossRef]

118. Hair, J.F.; Black, W.C.; Babin, B.J.; Anderson, R.E. Multivariate Data Analysis, 7th ed.; Pearson: Harlow, UK, 2014.

119. Rebetsiotis, G. Consumers Preference for Fresh Peaches. Master's Thesis, Aristotle University of Thessaloniki, Thessaloniki, Greece, 2009.

120. Hartmann, C.; Siegrist, M. Consumer perception and behaviour regarding sustainable protein consumption: A systematic review. Trends Food Sci. Technol. 2017, 61, 11-25. [CrossRef]

121. Lang, T.; Barling, D. Nutrition and sustainability: An emerging food policy discourse. Proc. Nutr. Soc. 2013, 72, 1-12. [CrossRef]

122. Karagiannis, G.; Velentzas, K. Explaining food consumption patterns in Greece. J. Agric. Econ. 1997, 48, 83-92. [CrossRef]

123. Lazaridis, P. Household meat demand in Greece: A demand systems approach using microdata. Agribus. Int. J. 2003, 19, 43-59. [CrossRef]

124. Hassapidou, M.N.; Fotiadou, E. Dietary intakes and food habits of adolescents in Northern Greece. Int. J. Food Sci. Nutr. 2001, 52, 109-116. [CrossRef]

125. Shuetleff, W.; Aoyagi, A. History of Soybeans and Soyfoods in Greece, the European Union, and Small Western European Countries: Extensively Annotated Bibliography and Soutcebook; Soyinfo Center: Lafayette, CA, USA, 2015; p. 5.

126. McGovern, E. Transport Behavior: A Role for Social Marketing. J. Nonprofit Public Sect. Mark. 2007, 17, 121-134. [CrossRef]

127. Campbell-Arvai, V.; Arvai, J.; Kalof, L. Motivating sustainable food choices the role of nudges, value orientation, and information provision. Environ. Behav. 2014, 46, 453-475. [CrossRef]

128. Jin, M.; Zhao, C. An analysis of consumer behavior and consumption intention on green agricultural products. China Rural Econ. 2008, 5, 44-55. (In Chinese)

129. Riediger, N.D.; Moghadasian, M.H. Patterns of fruit and vegetable consumption and the influence of sex, age and socio-demographic factors among Canadian elderly. J. Am. Coll. Nutr. 2008, 27, 306-313. [CrossRef]

130. Seyrek, I.H.; Gul, M. Factors Affecting Green Purchasing Behavior: A Study of Turkish Consumers. Int. J. Acad. Res. Bus. Soc. Sci. 2017, 7, 306-319. [CrossRef]

131. Verain, M.C.; Dagevos, H.; Antonides, G. Sustainable food consumption. Product choice or curtailment? Appetite 2015, 91, 375-384. [CrossRef]

132. Tripathi, A.; Singh, M.P. Determinants of sustainable/green consumption: A review. Int. J. Environ. Technol. Manag. 2016, 19, 316-358. [CrossRef] 
133. Ivy, T.G.C.; Road, K.S.; Lee, C.K.E.; Chuan, G.K. A survey of environmental knowledge, attitudes and behaviour of students in Singapore. Int. Res. Geogr. Environ. Educ. 1998, 7, 181-202. [CrossRef]

134. Ruby, M.B.; Heine, S.J. Meat, morals, and masculinity. Appetite 2011, 56, 447-450. [CrossRef]

135. Silva, S.S.; Machado, J.C.; Cruz, M. The influence of WOM and Peer Interaction in the Decision-Making Process of Generation Z within the family. Int. J. Mark. Commun. New Med. 2017, 2, 106-136.

136. Tilikidou, I.; Delistavrou, A. Fumbling the Greek Ethical Consumers' Profile. J. Res. Consum. 2018, 32, 32-69.

137. El Ansari, W.; Stock, C.; Mikolajczyk, R.T. Relationships between food consumption and living arrangements among university students in four European countries-a cross-sectional study. Nutr. J. 2012, 11, 28. [CrossRef]

138. Forleo, M.B.; Romagnoli, L.; Palmieri, N. Environmental values and willingness to pay for a protected area: A segmentation of Italian university students. Int. J. Sustain. Dev. World Ecol. 2019, 26, 45-56. [CrossRef]

139. Kyrkou, C.; Tsakoumaki, F.; Fotiou, M.; Dimitropoulou, A.; Symeonidou, M.; Menexes, G.; Biliaderis, C.G.; Michaelidou, A.M. Changing Trends in Nutritional Behavior among University Students in Greece, between 2006 and 2016. Nutrients 2018, 10, 64. [CrossRef] [PubMed]

(C) 2019 by the authors. Licensee MDPI, Basel, Switzerland. This article is an open access article distributed under the terms and conditions of the Creative Commons Attribution (CC BY) license (http://creativecommons.org/licenses/by/4.0/). 